\title{
Geochemical and mineralogical characteristics of calamines from the Olkusz zinc and lead ore district (South Poland)
}

\author{
Maciej Krzysztof SWĘD ${ }^{1, *}$ and Agata DUCZMAL-CZERNIKIEWICZ1 \\ 1 Adam Mickiewicz University, Institute of Geology, Krygowskiego 12, 61-680 Poznań, Poland
}

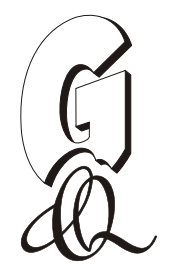

Swęd, M.K., Duczmal-Czernikiewicz, A., 2019. Geochemical and mineralogical characteristics of calamines from the Olkusz zinc and lead ore district (South Poland). Geological Quarterly, 63 (4): 699-710, doi: 10.7306/gq.1492

Associate editor: Tomasz Bajda

\begin{abstract}
The mineralogical and geochemical characteristics of calamines developed from chemical weathering within two different tectonic settings (tectonic horst and graben) are described. Calamines collected from the Olkusz-Pomorzany and the Bolesław zinc and lead mines were analysed geochemically by means of EMP and SEM-EDS and their mineralogical composition was identified by using reflected light microscopy and XRD analysis. The calamines from the Olkusz-Pomorzany mine are composed of marcasite, galena, cerussite, sphalerite, hemimorphite, smithsonite and goethite. Hemimorphite prevails over smithsonite and occurs in the vicinity of primary sulphides. The mineralogical composition of the calamines from the Bolesław area is less diverse. These are primarily composed of goethite and smithsonite, with a minor content of marcasite and remnant sphalerite. The mineral composition of weathering sites in the Olkusz-Pomorzany and Bolesław areas may reflect different geochemical conditions (from slightly acidic to alkaline $\mathrm{pH}$ values, from lower to higher $\mathrm{CO}_{2}$ partial pressure and solutions of different silica saturation) that could have changed over time. The mineralogical compositions of the calamines differ quantitatively and this could reflect the tectonic setting of the primary ore affecting the rate of chemical weathering.
\end{abstract}

Key words: calamines, chemical weathering, supergene zone, tectonic horst and graben, hemimorphite, smithsonite.

\section{INTRODUCTION}

Silesia-Kraków red calamines are classified as supergene mineralisation, primarily by direct replacement and partly by wall-rock replacement, of an MVT type zinc and lead deposit (Hitzman et al., 2003; Coppola et al., 2009). In the first case, secondary zinc and lead minerals replace primary sulphides in situ, without or with only insignificant removal of zinc. In the second case, a more significant amount of zinc is removed from the depleted protore ore and then further redeposited. The main factors causing this subdivision of supergene zinc and lead ore include the amount of sulphides, particularly the content of iron sulphides in the primary ore, as well as the tectonic structure. Iron sulphides catalyse oxidation, mainly of sphalerites from which zinc ions are released and removed in acid solution. Secondary zinc minerals precipitate as a result of gradual buffering of the acid solution by carbonate rocks which are the dominant hostof the MVT type zinc and lead deposit (Leach et al., 1992; Hitzmanet al., 2003). In the Olkusz mining district, which is part of the Silesia-Kraków zinc and lead province, the tectonic factor

\footnotetext{
* Corresponding author, e-mail: maciej.swed@amu.edu.pl
}

Received: March 18, 2019; accepted: July 16, 2019; first published online: October 28, 2019 significantly influenced non-sulphide mineralisation (Cabała, 2000, 2001, 2009; Coppola et al., 2009; Boni and Mondillo, 2015). Tectonic elements such as fissures, horsts and grabens may facilitate the oxidation of sulphide minerals. Tectonic horsts and grabens are features characteristic of the geological structure of the Olkusz ore district. In the vicinity of the Bolesław site, part of the primary ore is exposed within the tectonic horst, while the northern part of the zinc and lead ore is buried within the tectonic graben. Previous investigations revealed the occurrence of non-sulphide zinc and lead mineralisation in both these tectonic structures (Radwanek-Bąk, 1985; Cabała, 2000; Coppola, 2007; Coppola et al., 2009). Due to the different exposure of the primary ore to weathering, the physicochemical conditions should be different and secondary zinc and lead mineralisation might reflect these differences. Investigations revealed that the Polish calamines from the Olkusz ore district are composed mainly of smithsonite, $\mathrm{Zn}$-dolomite, cerussite and hemimorphite to a lesser degree (Żabiński, 1960, 1964; Radwanek-Bąk, 1985; Sutley et al., 1999; Boni and Large, 2003; Coppola, 2007; Coppola et al., 2009; Strzelska-Smakowska, 2010; Boni and Mondillo, 2015; Jerzykowska et al., 2014). Smithsonite and hemimorphite precipitate in slightly different physicochemical conditions; therefore, detailed mineralogical studies of calamines from two different weathering zones could help to reconstruct their geochemical environment. This type of investigation is essential for environmental geochemistry, because in these specific 


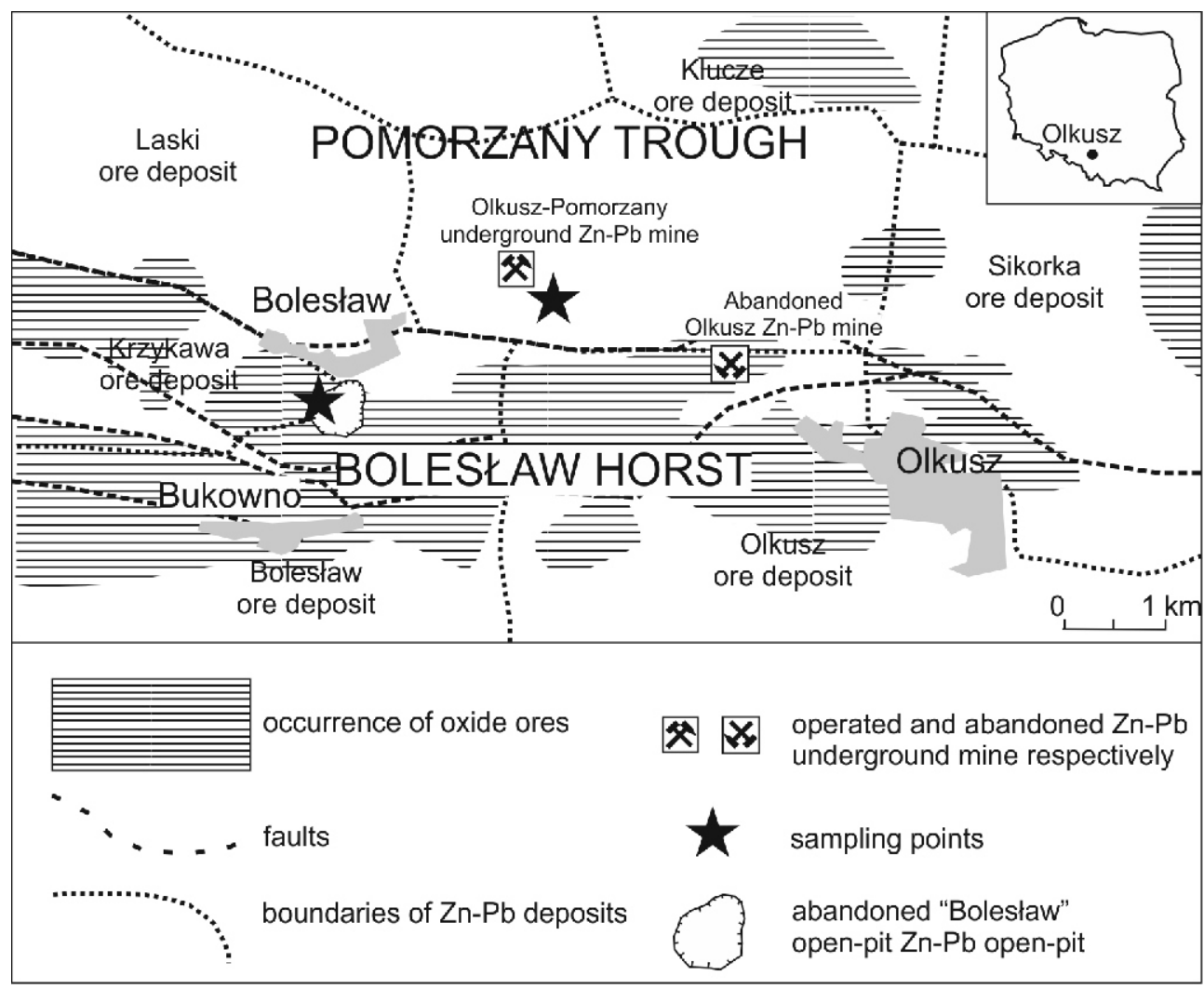

Fig. 1. Geological setting of the study area (modified from Cabała, 2000; Cabała et al., 2004)

physicochemical conditions, the secondary phase of zinc is resistant. Change in this, however, could release heavy metals to the geochemical cycle. The primary goals of our investigations were as follows:

- mineralogical and geochemical comparison of calamines developed within tectonic structures, based on primary sulphide mineralisation;

- an attempt to reconstruct weathering in different physicochemical conditions based on the mineralogical and geochemical composition of the calamines investigated;

- determination of the distribution of zinc, lead, iron and arsenic in the calamines collected from the weathering sites.

\section{GEOLOGICAL SETTING OF THE STUDY AREA}

The study area is located in the Olkusz ore district (Fig. 1), approximately $30 \mathrm{~km}$ north-west of Kraków. Primary and secondary supergene $\mathrm{Zn}-\mathrm{Pb}$ mineralisation occurs in the lithotypes of the Permo-Mesozoic Silesia-Kraków monocline that unconformably overlie Paleozoic rocks and form the upper part of the Upper Silesia Coal Basin and the Kraków-Myszków Zone (Górecka, 1993; Buła et al., 2008). The main zinc and lead mineralisation is concentrated in the Muschelkalk ore-bearing dolomites. In the Bolesław area, a certain amount of primary ore occurs within Roethian and Diplopora dolomites (Nieć et al., 1993). Calamines formed where Alpine tectonic movements exhumed and exposed the primary ore, facilitating its chemical weathering (Fig. 2; Żabiński, 1960; Cabała, 2001; Boni and Large, 2003). In the Olkusz ore district, primary mineralisation occurs within the tectonic graben under a thin cover, mostly consisting of Middle Triassic Diplopora dolomites, Upper Trias- sic non-marine Keuper claystones, Paleogene claystones, siltstones and Quaternary fluvioglacial sediments (Radwanek-Bąk, 1985; Fig. 2). The mineralogical composition of the primary zinc-lead Silesia-Kraków ores is relatively simple. These contain sphalerite, galena and marcasite, the latter more widespread than pyrite. The mineralogical composition is typical of an MVT type deposit of $\mathrm{Zn}$ and $\mathrm{Pb}$ ores (Sass-Gustkiewicz et al., 1982; Sass-Gustkiewicz and Dżułyński, 1998; Sutley et al., 1999; Kucha, 2003; Coppola et al., 2009), although according to some authors, certain geological, mineralogical and geochemical features of the Silesia-Kraków zinc and lead deposit are significantly different from the classical MVT type ore model (Kozłowski et al., 1996; Górecka et al., 1996). Based on isotopic investigations of $\mathrm{Zn}-\mathrm{Pb}$ sulphide minerals, some authors estimated the time of the primary mineralising event to be Early Cretaceous (Heijlen et al., 2003) or Middle Tertiary (Leach and Viets, 1992; Boni and Large, 2003). According to Sass-Gustkiewicz and Dżułyński (1998), though, ore-forming processes took place earlier, in the Late Triassic. According to Szuwarzyński (1996), the predominance of tabular forms of the ores, concordant with the Triassic bedding, demonstrates that the lithology of the host rocks was an important ore-forming factor. The alkaline environments of the host rocks and the fault networks, which were probably old Paleozoic faults rejuvenated during the Alpine orogeny, promoted precipitation of sulphide minerals (Gałkiewicz and Śliwiński, 1985; Górecka, 1993; Górecka et al., 1996; Szuwarzyński, 1996; Sass-Gustkiewicz and Dżułyński, 1998; Heijlen et al., 2003). Mixing of ascending ore fluids with low saline meteoric waters may have also promoted mineral precipitation (Kozłowski, 1995). According to Heijlen et al. (2003), Kozłowski (1995) and Kozłowski et al. (1996) the hydrothermal solutions were moderate to highly saline (20-23\%), dominated by $\mathrm{Na}-\mathrm{Ca}-\mathrm{Cl}$ ions with a temperature from 70 to $160^{\circ} \mathrm{C}$. 


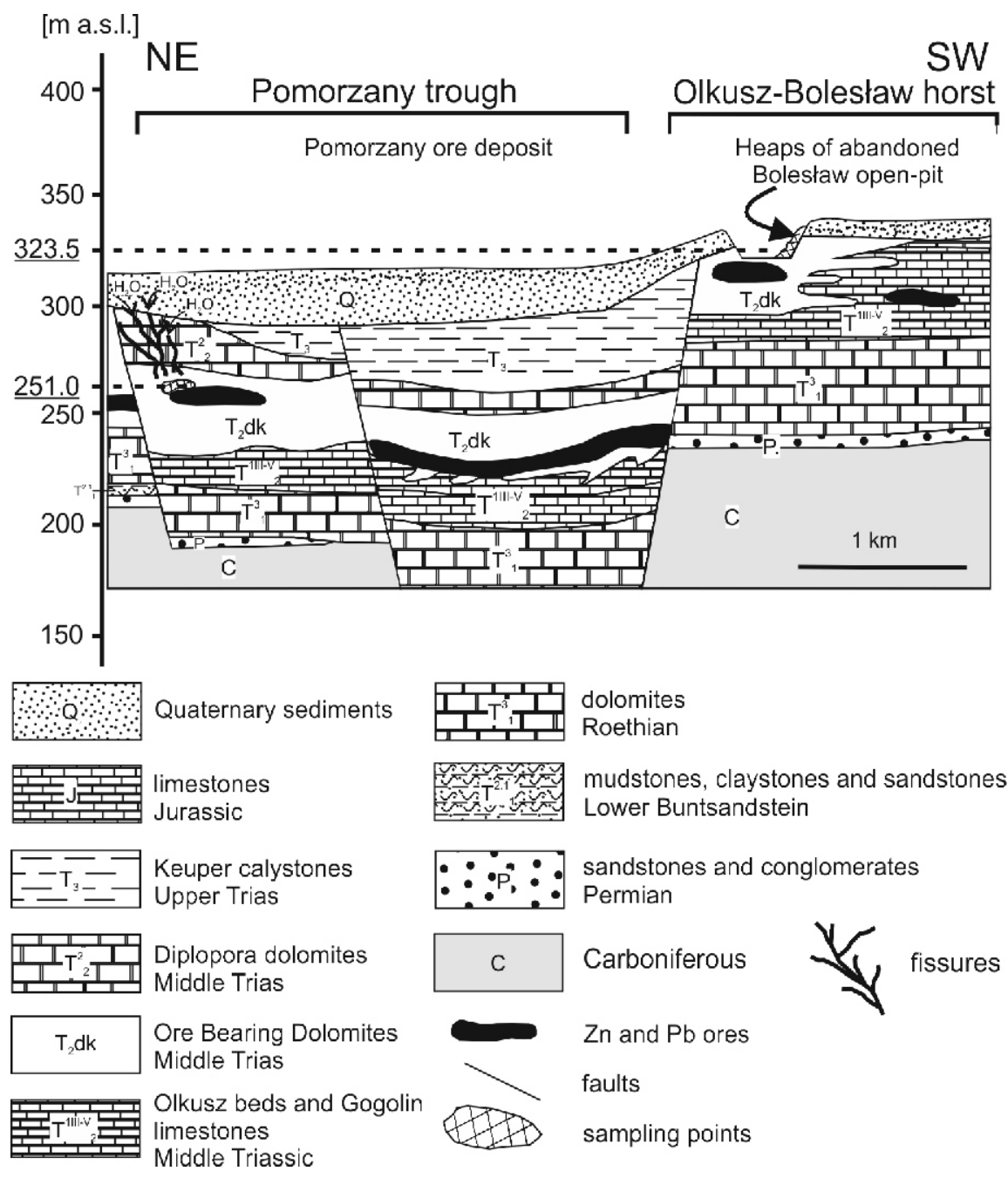

Fig. 2. Geological cross-section of the active Olkusz-Pomomorzany and the abandoned Bolesław zinc and lead mine (modified from Cabała et al., 2004)

The study of secondary $\mathrm{Zn}-\mathrm{Pb}$ minerals showed a significant content of smithsonite, monheimite, Zn-dolomite, Fe-hydroxides, cerussite, hydrozincite and a lower content of hemimorphite (Żabiński, 1960, 1964; Gałkiewicz and Śliwiński, 1985; Radwanek-Bąk, 1985; Osman, 1989; Sutley et al., 1999; Cabała, 2000, 2009; Boni and Large, 2003; Coppola et al., 2009; Strzelska-Smakowska, 2010; Boni and Mondillo, 2015). Supergene mineralisation occurs as lenticular, nest and tabular forms (Radwanek-Bąk, 1985; Coppola et al., 2009). Primary sulphides were replaced by supergene minerals formed through weathering processes (weathering metasomatism of carbonate rocks), as a result of buffering of acidic solutions by carbonate host rocks (Żabiński, 1960, 1964; Boni and Large, 2003; Hitzman et al., 2003; Reichert and Borg, 2008; Coppola et al., 2009). A certain amount of the smithsonite, zincian dolomite and cerussite could have crystallised partly during the primary ore-forming processes (Żabiński, 1960, 1964; Osman, 1989). The most favourable conditions for weathering of primary minerals occurred from the Late Cretaceous to the Middle Miocene, when the Alpine tectonic movements exposed a certain volume of primary ores to the surface (Coppola et al., 2009; Strzelska-Smakowska, 2010).

\section{METHODS AND MATERIALS}

Eight non-sulphide zinc and lead ore samples were collected from the surficial heaps in the western part of the re- claimed Bolesław open-pit (level $+323.5 \mathrm{~m}$ a.s.l.) and seven from the operating zinc and lead Pomorzany underground mine (level $+251.0 \mathrm{~m}$ a.s.l.; Figs. 1 and 2). Calamine samples in the underground mine were collected from the sites where the Keuper bed does not occur. The chemical analysisof the calamines was conducted by means of scanning electron microscopy (SEM-EDS, Hitachi S-3700N) at the Faculty of Geographical and Geological Sciences of the Adam Mickiewicz University in Poznań and by electron microprobe (EMP, Cameca SX100) at the Faculty of Geology of the University of Warsaw.

The mineral composition of the samples investigated was determined by X-ray diffraction (XRD, Thermo Electron model, ARL X'tra) at the Faculty of Geographical and Geological Sciences of the Adam Mickiewicz University in Poznań.

\section{RESULTS}

The mineralogical investigations identified primary (in order of increasing frequency): marcasite, galena, sphalerite and barite and secondary minerals (goethite, smithsonite, hemimorphite, cerussite and gypsum) in both study areas. Mineralogical and geochemical descriptions are provided separately for the Bolesław open-pit and the Olkusz-Pomorzany underground mine. 

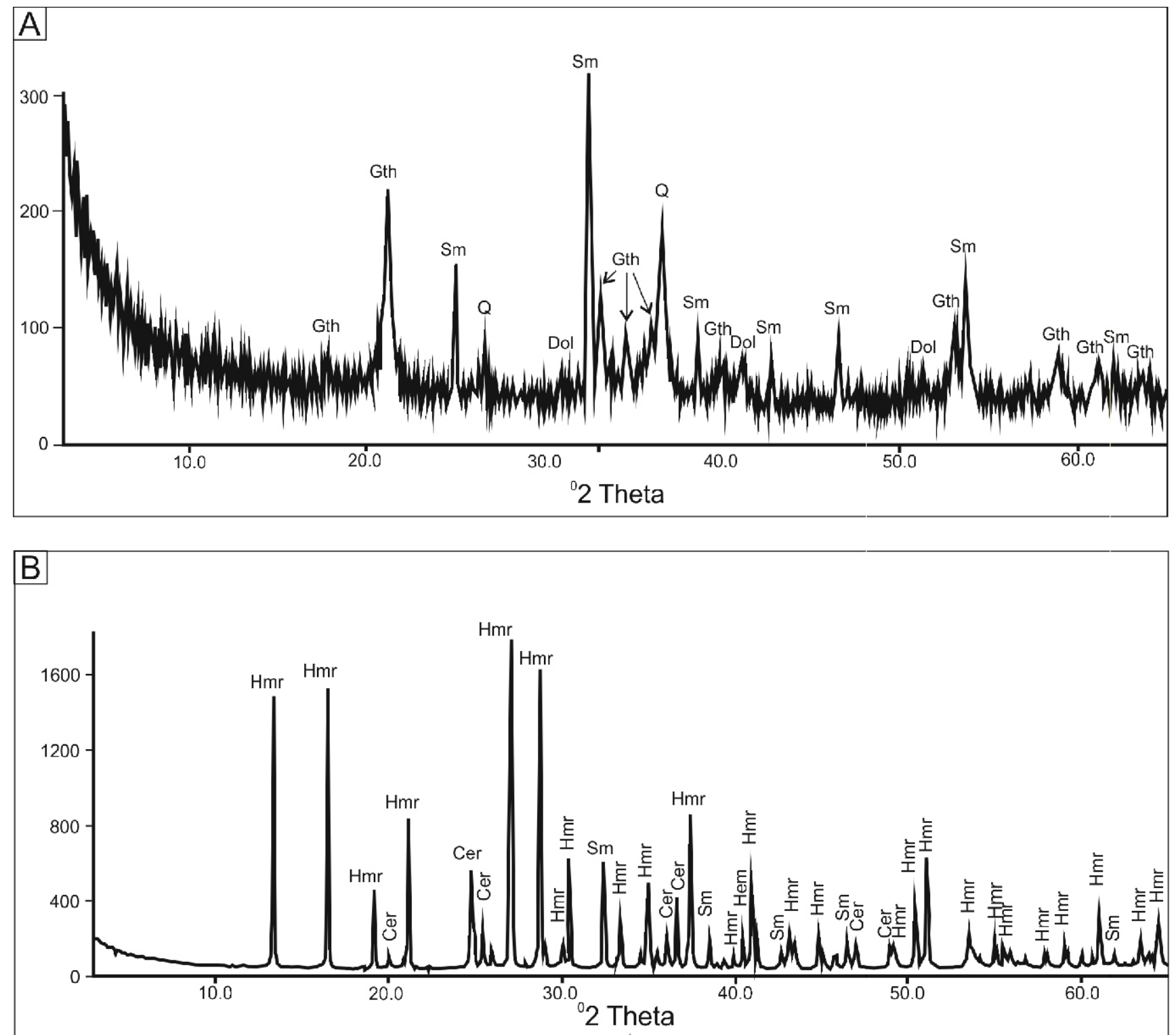

Fig. 3. Representative XRD patterns of the calamines from the Bolesław (A) and the Olkusz-Pomorzany area (B)

Cer - cerussite, Dol - dolomite, Gth - goethite, Hmr - hemimorphite, Q - quartz, Sm - smithsonite

\section{BOLESŁAW OPEN-PIT}

MINERALOGY

The mineral composition of the samples from the Bolesław open-pit is less differentiated than that of the samples from the Olkusz-Pomorzany weathering sites. The most abundant among the primary ore mineralsis marcasite, followed by rare sphalerite. Marcasite occurs as remnants within goethite and was distinguished only by means of microscope and SEM analyses. Sphalerite is less widespread and forms impregnations with partly etched surfaces. The most abundant secondary mineral in the investigated calamine was goethite, observed by microscope and confirmed by XRD analyses (Fig. 3A). Goethite occurs in the entire sample as amorphous, rarely in crystalline, phases, for mingearthy and collomorph aggregations. The XRD analysis revealed smithsonite as the second most widespread mineral after goethite (Fig. 3A). Smithsonite occurs as fibrous crystals, filling spaces between hemimorphites which form of platy crystals (Fig. 4). Hemimorphite was detected here in significantly lower amounts than smithsonite. The calamines are highly porous. Gangue minerals are mainly composed of dolomite and quartz.

\section{GEOCHEMISTRY}

Semi-quantitative chemical analyses of the secondary minerals, based on SEM-EDS, revealed a high content of iron, predominant among other transition metals (Fig. 5 and Table 1). Most of the iron occurs as oxides (Fig. 5 and Table 1), with lesser amounts as iron sulphides or as traces in sphalerite. Zinc is the second most widespread metal in the investigated samples (Table 1). The highest zinc content (48.88 wt.\%) was recorded in the sulphide form. However in most cases, zinc was detected in the secondary iron phases, where it reached relatively high values $(6.31 \mathrm{wt} . \%)$. Similarly to zinc, lead is concentrated only within secondary iron oxide minerals, but unlike zinc, it reaches only small amounts (in most analyses it did not 


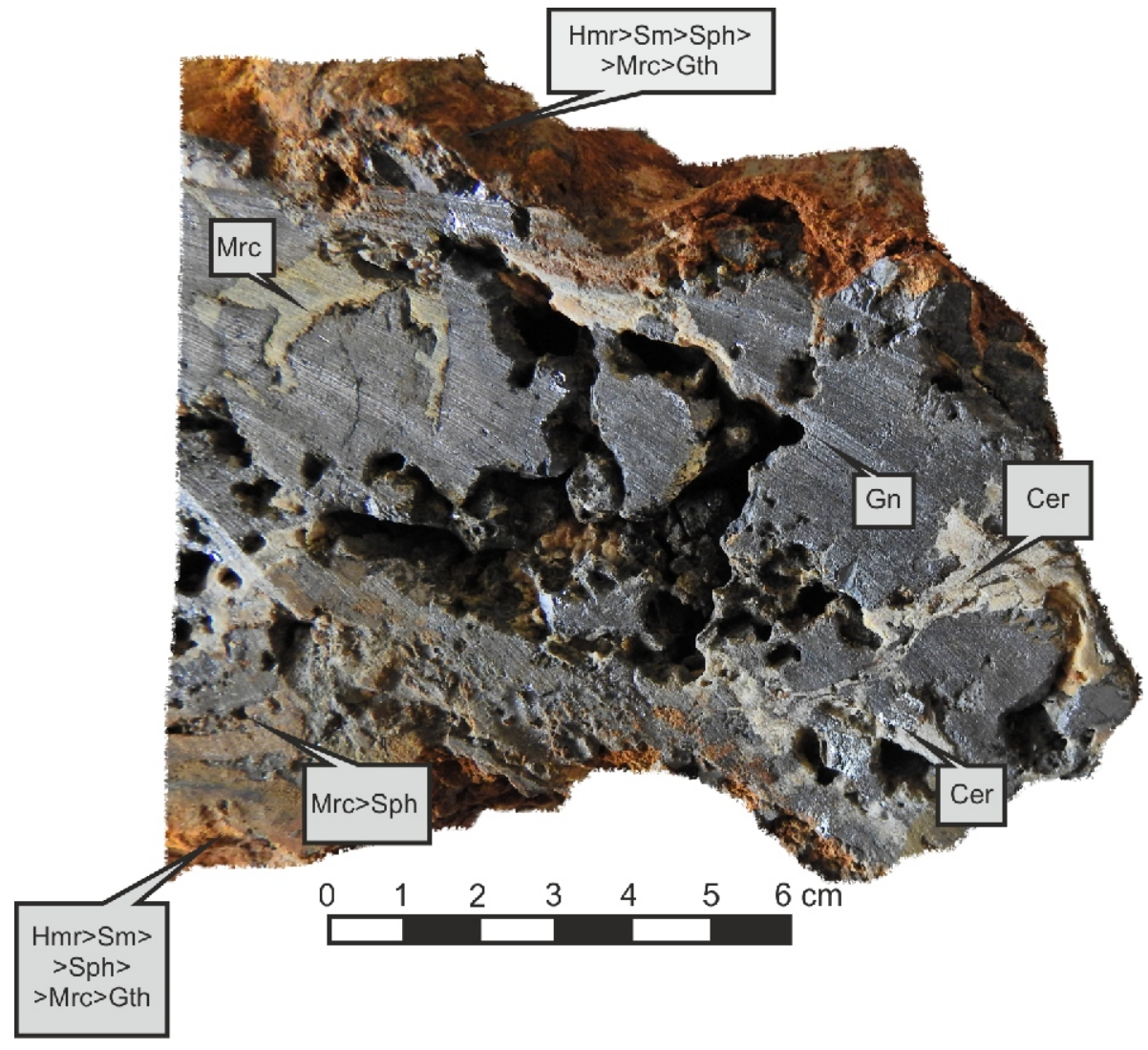

Fig. 4. Primary (Gn - galena, Mrc - marcasite, Sph - sphalerite) and secondary minerals (Cer - cerussite, Gth - goethite, Hmr - hemimorphite, Sm - smithsonite) distribution within calamine from the Olkusz-Pomorzany underground mine
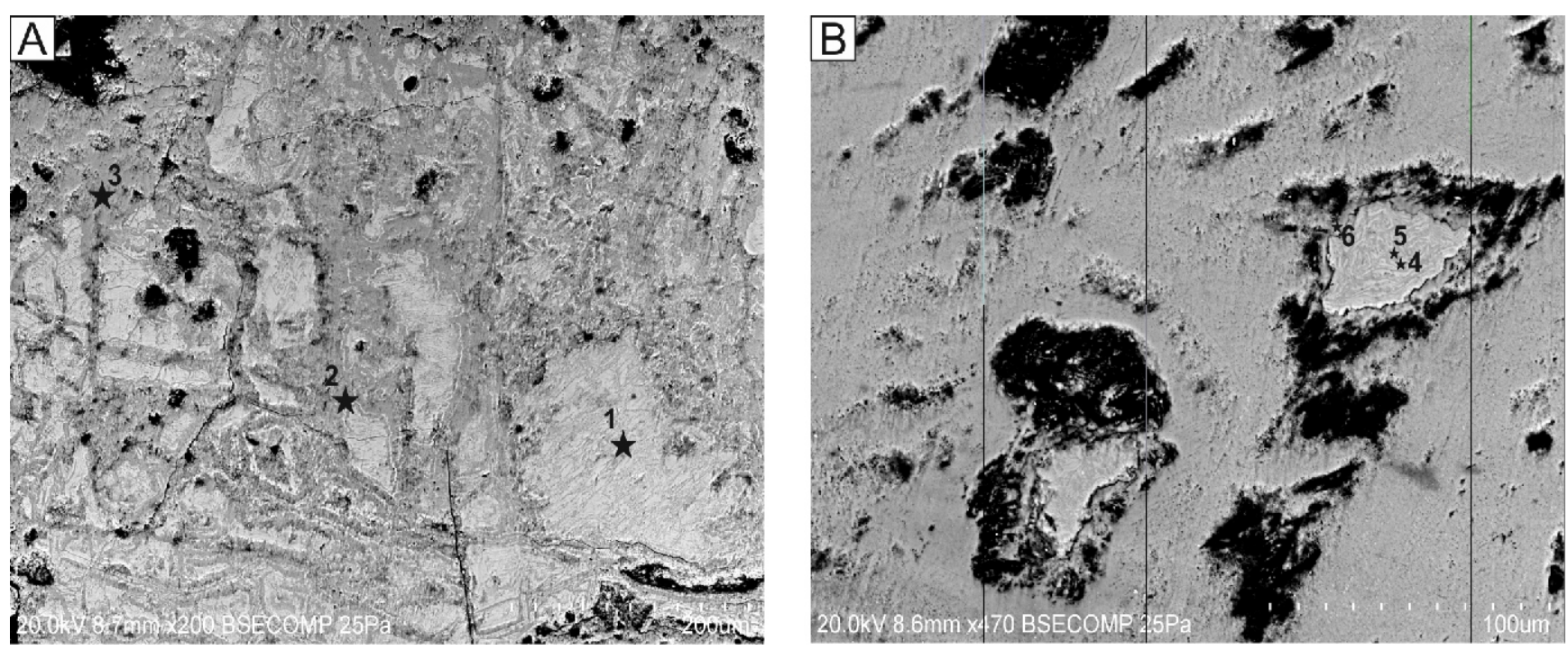

Fig. 5A, B - SEM-BSE images of calamine from the Bolesław open-pit

Emplacement of chemical analysis shown in Table 1; stars - points of semi-quantitative chemical analysis 
Ta ble 1

Results of SEM-EDS chemical investigations of calamine samples from the Bolesław area (in wt.\%)

\begin{tabular}{|l|c|c|c|c|c|c|}
\hline & \multicolumn{7}{|c|}{ Number of analyses } \\
\cline { 2 - 8 } & 1 & 2 & 3 & 4 & 5 & 6 \\
\hline $\mathrm{Na}_{2} \mathrm{O}$ & 1.74 & 1.39 & 3.24 & 1.36 & 1.54 & n.d. \\
\hline $\mathrm{MgO}$ & n.d. & n.d. & n.d. & n.d. & 0.73 & n.d. \\
\hline $\mathrm{Al}_{2} \mathrm{O}_{3}$ & n.d. & 0.28 & 0.37 & 0.3 & n.d. & 0.19 \\
\hline $\mathrm{SiO}_{2}$ & 4.06 & 2.59 & 4.41 & 3.78 & 3.83 & 6.43 \\
\hline $\mathrm{SO}_{3}$ & 0.76 & 0.64 & n.d. & n.d. & n.d. & 0.23 \\
\hline $\mathrm{CaO}$ & 0.13 & 0.15 & 0.24 & 0.22 & n.d. & 0.36 \\
\hline $\mathrm{Fe}_{2} \mathrm{O}_{3}$ & 88.65 & 91.19 & 84.55 & 91.68 & 91.03 & 85.86 \\
\hline $\mathrm{ZnO}$ & 3.07 & 3.76 & 6.31 & 2.25 & 2.08 & 5.34 \\
\hline $\mathrm{PbO}$ & 1.58 & n.d. & 0.88 & 0.40 & 0.78 & 1.59 \\
\hline
\end{tabular}

n.d. - not determined

reach 1 wt.\%; Table 1). No lead sulphides were detected at this site. A relatively high content of silicon was recorded, with the highest value of $6.86 \mathrm{wt} . \%$. Sulphur occurred as traces within secondary iron minerals ( $<1 \mathrm{wt} . \%)$, and as the main element with zinc and iron compounds.

\section{OLKUSZ-POMORZANY UNDERGROUND MINE}

MINERALOGY

This underground mine is characterized by the presence of both primary and secondary mineralisation. The primary ore assemblage mainly consists of well-crystallised marcasite, sphalerite and galena. Sphalerite occurs in significantly low amounts. Marcasites occur in brecciated structures (Fig. 5A) and traces of galena were found within cerussite in the EMP studies. Among gangue minerals, dolomite and barite prevail (Fig. 5A). The texture of the calamines is rather massive and significantly less porous than in the Bolesław open pit. Corrosive and skeletal textures occur in the vicinity of primary sulphides. Botryoidal texture was pervasive in the vicinity of primary sulphides. Among the secondary zinc minerals, hemimorphite and smithsonite prevail in the investigated calamines: hemimorphite significantly dominates over smithsonite (Figs. 3B and 4). The SEM and EMP analyses revealed the co-occurrence of those two zinc minerals, commonly as intergrowths (Fig. 6B). Hemimorphite and smithsonite occur only in the direct vicinity of primary sulphides (Fig. 4). In the investigated samples, the amount of smithsonite increases with increasing distance from the primary sulphide mineralisation and prevails over hemimorphite in the zones with a high content of goethite. The XRD analyses showed that both these secondary zinc minerals occur as crystalline phases. Next to hemimorphite and smithsonite, cerussite was also confirmed (Figs. 4 and 6B, C), occuring within veinlets in galena and on the rims of the galena crystals (Fig. 6C).

In most cases, cerussite has been observed as anhedral crystals, although cerussite pseudomorphs after galena were sometimes also observed. Cerussite was detected only in the zones where non-weathered primary lead mineralisation occurs and hemimorphite is the most abundant secondary zinc mineral. In comparison to the calamines from the Bolesław area, a significantly lower amount of goethite was observed in this underground mine. Goethite forms earthy aggregations and occurs mainly in the vicinity of marcasite (Fig. 6A), its amount being higher in the zones where lower amounts of galena and sphalerite were detected. Gypsum, confirmed by XRD analyses, forms efflorescences on the walls of the underground workings.

\section{GEOCHEMISTRY}

Silicates and carbonates were the main zinc mineral phases in the investigated calamines. The highest values of zinc (68.74 wt.\%) were found in hemimorphite (Table 2). Despite that, iron was present in sphalerites (Table 4) and the microprobe analyses (EMP) revealed a small content of that metal in the secondary zinc minerals as well (Tables 2 and 3 ). Cadmium was found only in smithsonites (1.69 wt.\%), where its values are higher than in sphalerites (0.1 wt. \%; Tables 3 and 4$)$. In comparison to hemimorphite, smithsonite accumulated a higher amount of lead. In both these secondary minerals the content of sulphur from remnant sulphides is very low $(<1$ wt.\%). Sulphides and carbonates are the most common chemical forms of lead (Table 5). High lead values (4.52 wt.\%) were detected in the secondary iron minerals (Table 7). Sulphides and oxides are the primary chemical forms of iron in the studied calamines (Tables 6 and 7 ). In the vicinity of marcasite, the chemical composition of goethite is more differentiated (Table 7). The goethites are particularly enriched in zinc (8.61 wt.\%), silicon (5.26 wt.\%) and lead (4.52 wt.\%). A characteristic feature of these goethites is their significantly high content of arsenic, which can reach a value of $4.50 \mathrm{wt} . \%$ (Table 7). A significantly lower content of arsenic (0.06 wt.\%) was detected in the galena.

\section{DISCUSSION}

In the calamine samples from the Olkusz-Pomorzany underground mine, silicates were the most abundant chemical form of zinc with a minor share of carbonates (Fig. 3B). The prevalence of hemimorphite over smithsonite was probably caused by alteration of marcasite, abundant in the vicinity of the weathering site. Unlike smithsonite, hemimorphite is stable in the conditions of a lower $\mathrm{pH}$ and lower $\mathrm{CO}_{2}$ partial pressure (Fig. 7; Takahashi, 1960; Osman, 1989; Hitzman et al., 2003). Lower $\mathrm{pH}$ was ensured by oxidation of marcasite, which released iron to the environment as sulphate ions [1] (Plumlee. 1999; Lara et al., 2015):

$$
\mathrm{FeS}_{2}+7 / 2 \mathrm{O}_{2}+\mathrm{H}_{2} \mathrm{O}=\mathrm{Fe}^{2+}+2 \mathrm{SO}_{4}^{2-}+2 \mathrm{H}^{+}
$$

Sphalerites were oxidised directly by oxide ions [2] or, more effectively, indirectly by ferric ions [3]:

$$
\begin{gathered}
\mathrm{ZnS}+2 \mathrm{O}_{2}=\mathrm{Zn}^{2+}+\mathrm{SO}_{4} \\
\mathrm{ZnS}+8 \mathrm{Fe}^{3+}+4 \mathrm{H}_{2} \mathrm{O}=\mathrm{Zn}^{2+}+8 \mathrm{Fe}^{2+}+\mathrm{SO}_{4}^{2-}+8 \mathrm{H}^{+}
\end{gathered}
$$

A small content of sphalerites in the investigated calamine samples from the Bolesław open-pit and the OlkuszPomorzany underground mine may have resulted from considerable admixtures of ferrous ions in the sphalerite crystal structure (Table 5). Low pH conditions promoted solubility of zinc and lead. Hemimorphite was a stable form of zinc within slightly acidic silica-saturated solutions (Fig. 7). Silicon ions could have been supplied from silicate admixtures in carbonate rocks 

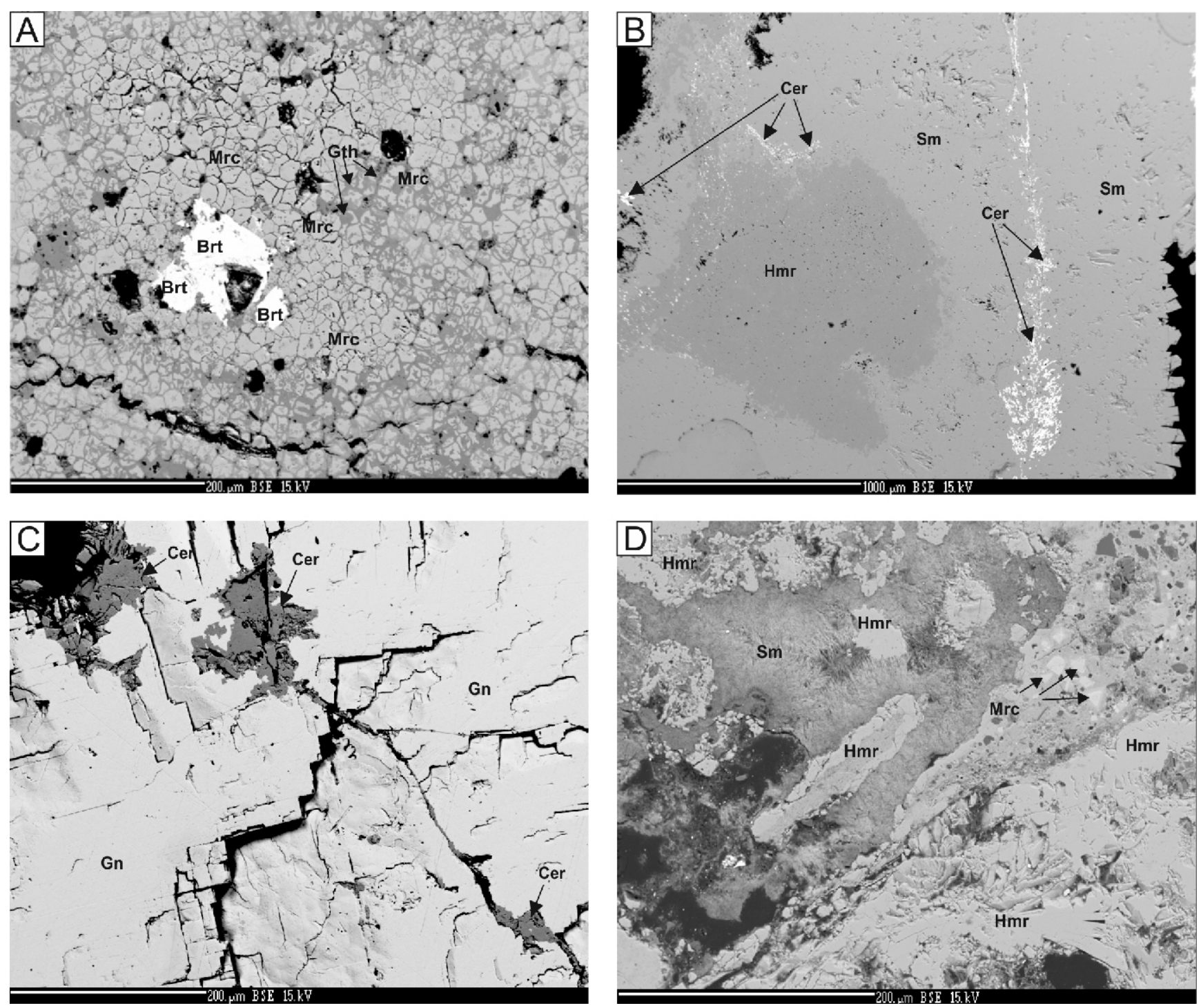

Fig. 6. EMP-BSE images of calamine from the Olkusz-Pomorzany study area

A - tectonically crushed marcasite crystals (Mrc) enriched in arsenic, goethite (Gth) infills the spaces between marcasite, in the samples investigated barite (Brt) occurs in the vicinity of marcasite; $\mathbf{B}$ - smithsonite $(\mathrm{Sm})$ and hemimorphite $(\mathrm{Hmr})$ overgrowth adjacent to primary galena crystals replaced by cerussite (Cer); $\mathbf{C}$ - galena crystals $(\mathrm{Gn}$ ) replaced by cerussite (Cer) within cleavages and edges; $\mathbf{D}$ - acicular smithsonites $(\mathrm{Sm})$ infill space between hemimorphite $(\mathrm{Hmr})$ and partly altered marcasite $(\mathrm{Mrc})$ assemblages

Table 2

WDS geochemical analyses of hemimorphite from the Olkusz-Pomorzany weathering sites (in wt.\%)

\begin{tabular}{|c|c|c|c|c|c|c|c|c|}
\hline & \multicolumn{8}{|c|}{ Hemimorphite } \\
\hline & \multicolumn{8}{|c|}{ Number of analyses } \\
\hline & 1 & 2 & 3 & 4 & 5 & 6 & 7 & 8 \\
\hline $\mathrm{SiO}_{2}$ & 23.461 & 26.122 & 26.285 & 24.933 & 24.951 & 24.805 & 24.301 & 25.129 \\
\hline $\mathrm{ZnO}$ & 68.744 & 69.151 & 70.139 & 71.563 & 72.462 & 70.971 & 73.719 & 73.111 \\
\hline $\mathrm{MnO}$ & n.d. & n.d. & 0.064 & 0.041 & n.d. & n.d. & n.d. & n.d. \\
\hline $\mathrm{Fe}_{2} \mathrm{O}_{3}$ & 0.137 & 0.434 & 0.652 & 1.404 & 1.399 & 0.776 & 0.935 & 0.717 \\
\hline $\mathrm{CuO}$ & n.d. & n.d. & 0.097 & 0.013 & 0.007 & n.d. & n.d. & 0.088 \\
\hline $\mathrm{PbO}$ & 0.409 & n.d. & 0.014 & 0.129 & n.d. & 0.257 & 0.107 & 0.264 \\
\hline $\mathrm{CdO}$ & 0.007 & n.d. & n.d. & n.d. & n.d. & n.d. & n.d. & n.d. \\
\hline $\mathrm{SO}_{3}$ & n.d. & 0.028 & 0.031 & 0.04 & 0.041 & 0.035 & 0.007 & 0.054 \\
\hline Total & 92.76 & 95.73 & 97.28 & 98.12 & 98.86 & 96.85 & 99.07 & 99.36 \\
\hline
\end{tabular}


WDS geochemical analyses of smithsonite from the Olkusz-Pomorzany weathering sites (in wt.\%)

\begin{tabular}{|l|c|c|c|c|}
\hline \multirow{2}{*}{} & \multicolumn{4}{|c|}{ Smithsonite } \\
\cline { 2 - 5 } & \multicolumn{4}{|c|}{ Number of analyses } \\
\cline { 2 - 5 } & 1 & 2 & 3 & 4 \\
\hline $\mathrm{SiO}_{2}$ & 0.034 & 0.014 & 1.068 & n.d. \\
\hline $\mathrm{ZnO}$ & 59.249 & 60.184 & 66.737 & 69.095 \\
\hline $\mathrm{FeO}$ & 0.03 & n.d. & 1.087 & 1.05 \\
\hline $\mathrm{CaO}$ & 0.636 & 0.623 & 0.416 & 1.352 \\
\hline $\mathrm{PbO}$ & 1.129 & 0.996 & 0.812 & 1.277 \\
\hline $\mathrm{SO}_{3}$ & 0.02 & 0.088 & 0.539 & 0.028 \\
\hline $\mathrm{As}_{2} \mathrm{O}_{3}$ & n.d. & 0.058 & n.d. & n.d. \\
\hline $\mathrm{CdO}$ & 1.688 & 1.562 & n.d. & n.d. \\
\hline $\mathrm{Cl}$ & n.d. & n.d. & 0.043 & 0.007 \\
\hline $\mathrm{MgO}$ & n.d. & 0.123 & n.d. & n.d. \\
\hline Total & 62.786 & 63.647 & 70.702 & 72.809 \\
\hline
\end{tabular}

n.d. - not determined

Table 4

\section{WDS geochemical analyses of sphalerite from the Olkusz-Pomorzany} weathering sites (in wt.\%)

\begin{tabular}{|l|c|c|}
\hline \multirow{2}{*}{} & \multicolumn{2}{|c|}{ Sphalerite } \\
\cline { 2 - 3 } & \multicolumn{2}{|c|}{ Number of analyses } \\
\cline { 2 - 3 } & 1 & 2 \\
\hline $\mathrm{S}$ & 32.253 & 32.632 \\
\hline $\mathrm{Zn}$ & 63.74 & 61.925 \\
\hline $\mathrm{Fe}$ & 2.894 & 3.028 \\
\hline $\mathrm{Co}$ & 0.051 & n.d. \\
\hline $\mathrm{Cu}$ & 0.132 & 0.052 \\
\hline $\mathrm{Ga}$ & 0.11 & n.d. \\
\hline $\mathrm{As}$ & 0.012 & n.d. \\
\hline $\mathrm{Se}$ & n.d. & 0.057 \\
\hline $\mathrm{Cd}$ & 0.002 & 0.1 \\
\hline $\mathrm{Ag}$ & n.d. & 0.028 \\
\hline $\mathrm{Sn}$ & 0.009 & 0.006 \\
\hline $\mathrm{Pb}$ & n.d. & 0.254 \\
\hline $\mathrm{Sb}$ & 0.015 & 0.009 \\
\hline $\mathrm{Mn}$ & n.d. & 0.031 \\
\hline $\mathrm{Total}$ & 99.218 & 98.122 \\
\hline
\end{tabular}

n.d. - not determined

(Żabiński, 1960) or by the Keuper claystones layer that lies above. Neutral and basic $\mathrm{pH}$ conditions of carbonate rocks promoted solubility of silicon, which probably occurred as weak silicic acid (Reichert and Borg, 2008). The supply of silicon to the solution could have been caused by incongruent buffering reactions between acid solutions and silicate rock-forming minerals, where hydrogen ions were incorporated into weak silicic acid [4] (Plumlee, 1999; Lottermoser, 2010):

$$
\begin{gathered}
2 \mathrm{MeAISi}_{3} \mathrm{O}_{8}+2 \mathrm{H}^{+}+4 \mathrm{H}_{2} \mathrm{O}=2 \mathrm{Me}+\mathrm{Al}_{2} \mathrm{Si}_{4} \mathrm{O}_{10}(\mathrm{OH})_{2}+[4] \\
2 \mathrm{H}_{4} \mathrm{SiO}_{4}
\end{gathered}
$$

WDS geochemical analyses of cerussite from the Olkusz-Pomorzany weathering sites (in wt.\%)

\begin{tabular}{|l|c|c|c|c|}
\hline \multirow{2}{*}{} & \multicolumn{4}{|c|}{ Cerussite } \\
\cline { 2 - 5 } & \multicolumn{4}{|c|}{ Number of analyses } \\
\cline { 2 - 5 } & 1 & 2 & 3 & 4 \\
\hline $\mathrm{As}_{2} \mathrm{O}_{3}$ & n.d. & 0.02 & n.d. & 0.021 \\
\hline $\mathrm{MnO}$ & 0.006 & 0.112 & n.d. & 0.045 \\
\hline $\mathrm{Fe}_{2} \mathrm{O}_{3}$ & n.d. & 0.12 & n.d. & 0.022 \\
\hline $\mathrm{SiO}_{2}$ & n.d. & n.d. & n.d. & 0.019 \\
\hline $\mathrm{PbO}$ & 85.045 & 82.748 & 83.446 & 83.79 \\
\hline $\mathrm{CaO}$ & 0.048 & 0.341 & 0.122 & 0.36 \\
\hline $\mathrm{ZnO}$ & n.d. & n.d. & n.d. & 1.566 \\
\hline $\mathrm{Total}$ & 85.099 & 83.341 & 83.568 & 85.823 \\
\hline
\end{tabular}

n.d. - not determined

Table 6

WDS geochemical analyses of marcasite from the Olkusz-Pomorzany weathering sites (in wt.\%)

\begin{tabular}{|l|c|c|c|}
\hline \multirow{2}{*}{} & \multicolumn{3}{|c|}{ Marcasite } \\
\cline { 2 - 4 } & 1 & 2 & 3 \\
\hline $\mathrm{S}$ & 50.935 & 52.615 & 52.448 \\
\hline $\mathrm{Fe}$ & 46.504 & 47.23 & 47.141 \\
\hline $\mathrm{Co}$ & n.d. & n.d. & 0.047 \\
\hline $\mathrm{Ni}$ & 0.114 & n.d. & 0.039 \\
\hline $\mathrm{Cu}$ & n.d. & 0.061 & n.d. \\
\hline $\mathrm{Zn}$ & n.d. & n.d. & 0.055 \\
\hline $\mathrm{As}$ & 2.713 & 0.007 & 0.734 \\
\hline $\mathrm{Pb}$ & n.d. & n.d. & n.d. \\
\hline $\mathrm{Cd}$ & n.d. & 0.074 & n.d. \\
\hline $\mathrm{Sb}$ & n.d. & n.d. & 0.002 \\
\hline $\mathrm{Ag}$ & 0.083 & 0.087 & 0.058 \\
\hline $\mathrm{Au}$ & 0.129 & 0.06 & 0.078 \\
\hline $\mathrm{Total}$ & 100.477 & 100.134 & 100.602 \\
\hline
\end{tabular}

n.d. - not determined

where: $\mathrm{Me}-\mathrm{Na}, \mathrm{K}, \mathrm{Ca}$

The occurrence of hemimorphite may have suggested that the acid production was slightly higher than the buffering capabilities of the carbonate rocks in the immediate vicinity of the marcasites. The dominance of smithsonite in the calamines from the Bolesław open-pit and some amounts of it in the Olkusz-Pomorzany underground mine indicates that this was the most comprehensive product of buffering acid solutions by carbonate rocks within these MVT type zinc and lead deposits. Smithsonite precipitates as a result of bonding zinc ions with carbonate or bicarbonate ions (Reichert and Borg, 2008). Bicarbonate ions were a product of a reaction of dolomite with hydrogen ions [5] (Blowes et al., 1994; Reichert and Borg, 2008):

$$
\mathrm{CaMg}\left(\mathrm{CO}_{3}\right)_{2}+2 \mathrm{H}^{+}=\mathrm{Ca}^{2+}+\mathrm{Mg}^{2+}+2 \mathrm{HCO}_{3}^{-}
$$


Ta ble 7

WDS geochemical analyses of secondary iron minerals from the Olkusz-Pomorzany weathering sites (in wt.\%)

\begin{tabular}{|c|c|c|c|}
\hline & \multicolumn{3}{|c|}{ Goethite } \\
\hline & \multicolumn{3}{|c|}{ Number of analyses } \\
\hline & 1 & 2 & 3 \\
\hline $\mathrm{Na}_{2} \mathrm{O}$ & 0.407 & n.d. & n.d. \\
\hline $\mathrm{As}_{2} \mathrm{O}_{3}$ & 4.499 & n.d. & n.d. \\
\hline $\mathrm{SiO}_{2}$ & 3.988 & 5.257 & 4.915 \\
\hline $\mathrm{MgO}$ & 0.045 & n.d. & n.d. \\
\hline $\mathrm{Fe}_{2} \mathrm{O}_{3}$ & 66.242 & 67.737 & 63.037 \\
\hline $\mathrm{MnO}$ & 0.026 & 0.069 & 0.015 \\
\hline $\mathrm{NiO}$ & 0.025 & n.d. & n.d. \\
\hline $\mathrm{SO}_{3}$ & 0.286 & 0.31 & 0.413 \\
\hline $\mathrm{K}_{2} \mathrm{O}$ & 0.018 & n.d. & n.d. \\
\hline $\mathrm{TiO}_{2}$ & 0.024 & n.d. & n.d. \\
\hline $\mathrm{CaO}$ & 0.54 & n.d. & 0.157 \\
\hline $\mathrm{PbO}$ & 1.273 & 4.515 & 4.288 \\
\hline $\mathrm{P}_{2} \mathrm{O}_{5}$ & 0.052 & n.d. & n.d. \\
\hline $\mathrm{ZnO}$ & 8.471 & 7.601 & 8.612 \\
\hline Total & 85.896 & 85.49 & 81.437 \\
\hline
\end{tabular}

n.d. - not determined

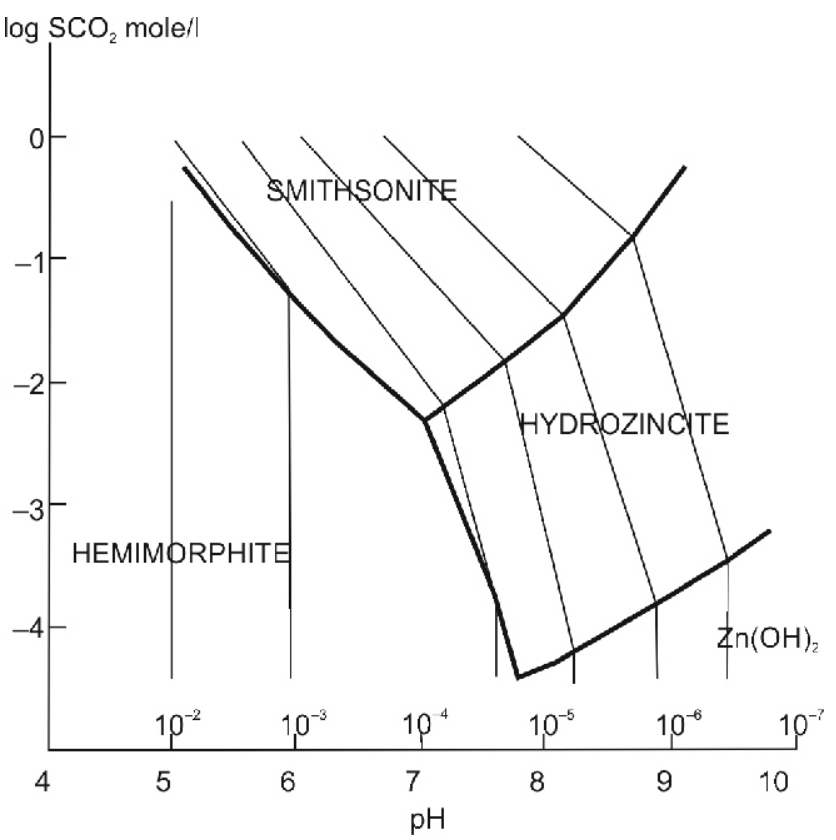

Fig. 7. Stability field of smithsonite, hemimorphite, hydrozincite and zinc hydroxide in silica-saturated solution at $25^{\circ} \mathrm{C}$ (Takahashi, 1960)

The carbonates were a product of bicarbonates hydrolysis. Zinc ions in solutions migrated as sulphate ions, which reacted with bicarbonate or carbonate acid [6] and precipitated as smithsonite:

$$
\mathrm{ZnSO}_{4}+\mathrm{H}_{2} \mathrm{CO}_{3}=\mathrm{ZnCO}_{3}+\mathrm{SO}_{4}^{2-}+\mathrm{H}_{2}^{+}
$$

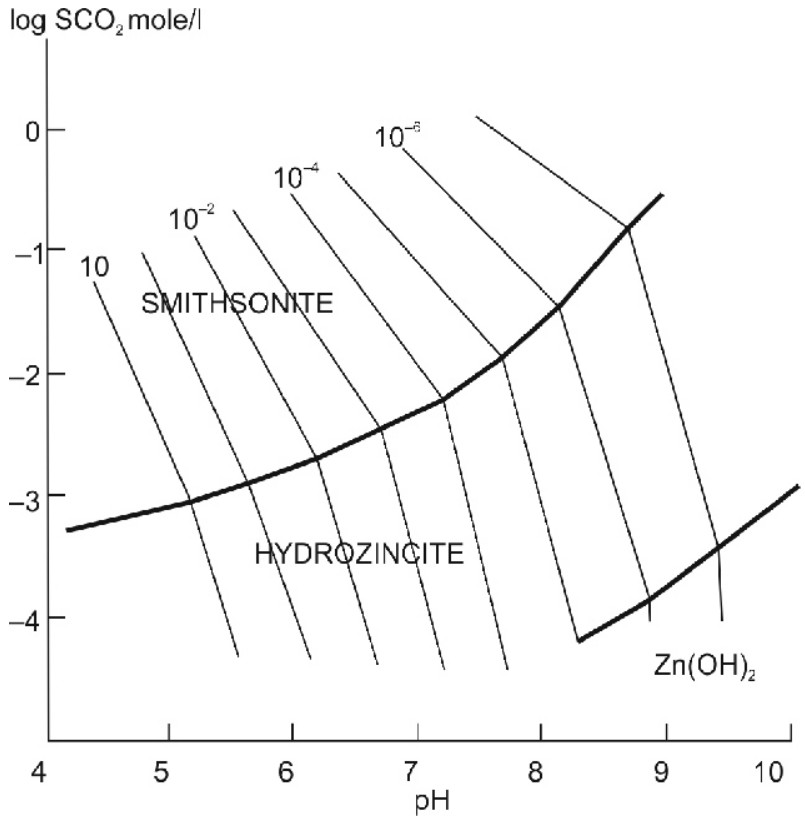

Fig. 8. Stability field of smithsonite, hydrozincite and zinc hydroxide in silica-free solutions at $25^{\circ} \mathrm{C}$ (Takahashi, 1960)

Gypsum, observed in the weathering sites within the Olkusz-Pomorzany underground mine, is a widespread by-product of smithsonite crystallisation. The above chemical reactions imply that in the silica-free solution, the most stable conditions for smithsonite included $\mathrm{pH}$ values from neutral to basic and high $\mathrm{CO}_{2}$ partial pressures (Fig. 8; Takahashi, 1960; Hitzman et al., 2003; McPhail et al., 2003; Reichert and Borg, 2008). The co-occurrence of two different types of chemical zinc phases in the samples from the Olkusz-Pomorzany underground mine (Figs. 4 and 6B, D) suggests that the conditions of crystallisation $\left(\mathrm{CO}_{2}\right.$ partial pressure, $\mathrm{pH}$ values, $\mathrm{SO}_{4}$ activity, silica saturation) may have been changing over time. Different chemical reactions that occurred in the oxidation process within the calamines from the Bolesław open-pit, where the content of primary sulphide minerals, especially of marcasite, was significantly lower, did not contribute to a decrease in $\mathrm{pH}$. The prevalence of smithsonite over hemimorphite in the Bolesław open-pit may also have been caused by a significantly lower content of silicate minerals above the ore-bearing dolomite, considered the main source of silicon ions, in this area. In this case, only smithsonite could have crystallised as the main secondary zinc phase. Zinc ions liberated from primary ore could have partly replaced magnesium ions within dolomite, forming zincian dolomite (Żabiński, 1960, 1964, 1986; Garavelli et al., 1982; Boni et al., 2011). As opposed to galena, sphalerite at both the investigated sites was almost completely replaced by secondary zinc forms. Domination of iron-rich sphalerite (marmatite) could have promoted its chemical weathering as a result of admixture of iron, which catalyzed the oxidation of sulphides (Plumlee, 1999). Galena and cerussite were found only in the Olkusz-Pomorzany underground mine. No primary or secondary lead minerals were detected in the Bolesław open-pit, where lead occurred in significantly lower content as an adsorbed form within secondary iron minerals. Similarly to smithsonite, cerussite can form as a result of buffering of the acid solutions by carbonate rocks [7] (Reichert and Borg, 2008; Szczerba and Sawłowicz, 2009; Lara et al., 2011).

$$
\mathrm{PbSO}_{4}+\mathrm{H}_{2} \mathrm{CO}_{3}=\mathrm{PbCO}_{3}+\mathrm{SO}_{4}^{2-}+2 \mathrm{H}^{+}
$$




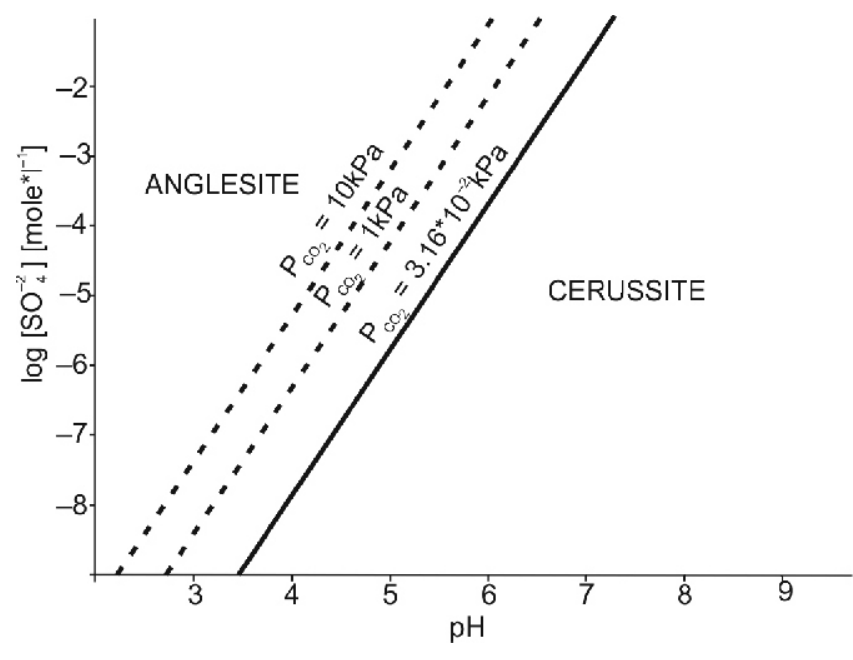

Fig. 9. Stability field of anglesite and cerussite relative with reference to sulphate ion activity, $\mathrm{CO}_{2}$ partial pressure and $\mathrm{pH}$ values (Reichert and Borg, 2008)

The weathering of galena under calcareous conditions in soils was simulated by Lara et al. (2011). Żabiński suggested that cerussite within the Silesia-Kraków zinc and lead deposits (Żabiński, 1960) could have been preceded by anglesite that is the stable secondary form of lead in an acidic environment $(\mathrm{pH}<6)$ in the oxidation zone. Mineralogical studies described in this work did not confirm the presence of anglesite, which could show that cerussite crystallises without anglesite transition forms in alkaline conditions. Similar conclusions were already made by Szczerba and Sawłowicz (2009). Cerussite, as the main secondary lead mineral, is associated with conditions of high $\mathrm{CO}_{2}$ partial pressure and neutral to alkaline $\mathrm{pH}$ conditions with low sulphate ion activity (Fig. 9; Cabała, 1996; Reichert and Borg, 2008; Szczerba and Sawłowicz, 2009). Cerussite occurred as galena coatings, preventing further oxidation (Fig. 6C).

A lesser amount of primary minerals within the calamines in the Bolesław open-pit was probably caused by a longer exposure of the ore samples to surficial conditions facilitating chemical weathering. However, a lack of hemimorphite and the the prevalence of smithsonite as the main secondary zinc phase could have been related to a low content of marcasite in the deposit. Unlike in the Olkusz-Pomorzany area, secondary iron minerals (mainly goethite) prevail in the mineral composition of calamines sampled in the Bolesław open-pit. Secondary iron phases were enriched in elements such as zinc, lead and arsenic. The concentration of these elements was associated with sorption properties of the secondary iron phases, which captured zinc, lead and arsenic from the geochemical cycle, as previously observed within other supergene zones (e.g., Jerzykowska et al., 2014; Swęd and Niedzielski, 2018). Higher concentrations of arsenic in the secondary iron minerals, adjacent to marcasite, suggest that the above sulphide was the main source of As (Fig. 6A).

The lack of any traces of primary and secondary lead minerals and the regular occurrence of smithsonite in the Bolesław open-pit, suggest that the non-sulphide zinc and lead minerals partially originated as wall-rock replacements. In this type of non-sulphide zinc and lead deposit, smithsonite is the dominant secondary mineral (Hitzman et al., 2003). Zinc, as soluble sulphate ions, may have migrated from the oxidised primary ore and precipitated as a result of buffering solutions by carbonate rocks. Galena, often coated by cerussite, was a more resistant sulphide mineral and might have remained within the primary ore (e.g., in the Olkusz-Pomorzany underground mine).

Although the mineralogical composition of the calamines from the Kraków-Silesia zinc and lead ore deposit is relatively well known, this study reveals that the quantitative share of the non-sulphide zinc and lead minerals might have been influenced by the tectonic structure. Within the Pomorzany trough of the Olkusz-Pomorzany underground mine, a lower rate of chemical weathering preserved a higher content of marcasite. This was caused by insignificant exposure of the primary ore to weathering factors such as oxygen and water. The alteration of marcasite partly contributed to a change in the physicochemical conditions, reflected in the secondary zinc and lead assemblages. The alteration of primary minerals within the Pomorzany trough occurs in a tectonically disturbed ore deposit, where fractures facilitate percolation of meteoric waters down to greater depths. According to previous investigations, hemimorphite is characteristic of the final weathering stages (Żabiński, 1960, 1964), during which dissolved silica ions had been delivered by buffered solutions. Hemimorphite, found within weathering sites of the Olkusz-Pomorzany underground mine in very high concentrations, may also be related to the initial weathering stages, where high concentrations of unweathered or partly altered primary sulphide minerals were observed. Silica ions may have been supplied by descending solutions, which did not interact with the ore body. The confirmation of which secondary zinc mineral precipitates first (hemimorphite or smithsonite?) requires further investigation. In the Bolesław open-pit, the primary ore within the tectonic horst was exposed during the Alpine orogeny. Therefore, the rate of chemical transformation of the primary ore was faster than within the Pomorzany trough (Cabała, 2001, 2009). This hypothesis may be supported by the abundance of goethite, the low amount of remnant primary sulphides minerals and by the occurrence of smithsonite as the main non-sulphide zinc mineral. Traces of hemimorphite were probably the effect of a low content of marcasite, whose chemical weathering could have lowered the $\mathrm{pH}$ values.

Based on the above discussion, the differences in the mineral composition reflect different geochemical conditions of weathering within the Bolesław and Olkusz-Pomorzany mining localities: these are directly related totectonic structure, which can either promote or inhibit the alteration of the primary ore.

\section{CONCLUSIONS}

1. The mineralogical and geochemical investigations of calamines from both the supergene sites confirm that the primary ore consisted mainly of marcasite, sphalerite and galena, whereas the secondary ore contains cerussite, hemimorphite, smithsonite and goethite. The primary ore collected from the tectonic graben was less weathered and contained more sulphides than the ore within the tectonic horst.

2. In the tectonic graben, hemimorphite prevailed over smithsonite, while within the tectonic horst smithsonite was the dominant zinc phase. A significantly higher content of hemimorphite was observed within the supergene zone of the Olkusz-Pomorzany underground mine, compared with a previously conducted study of calamines from this mine. Lead formed secondary cerussite, which occurred only within this underground mine.

3. The predominance of hemimorphite over smithsonite, the content of cerussite and gypsum, as well as the lack of anglesite within the Olkusz-Pomorzany area suggest slightly different physicochemical conditions at the investigated weathering 
sites, these being prone to changes in weathering characteristics over time.

4. The only primary iron mineral which was found in both mining areas is marcasite, whereas secondary goethite, developed from marcasite, prevails within the Bolesław site. Zinc, lead and arsenic commonly accumulated in goethite at higher concentrations than in the other minerals. The primary source of these metals was in sulphides and - as revealed at the microscale - arsenic was undoubtedly derived from marcasite.

5. The predominance of smithsonite over hemimorphite within the Bolesław open-pit may have been caused by the lack of siliciclastic rocks in the upper part of the succession, which has been always considered as the main source of silicon ions. Moreover, the possibility of different weathering conditions and times should be considered a possible cause of such quantitative diversification in the secondary minerals.
6. Calamines from the tectonic horst and graben areas may represent direct replacement of the primary ore with a minor share of wall-rock replacement within the horst structures.

Acknowledgments. The XRD and SEM-EDS analysis were financially supported by the Institute of Geology, A. Mickiewicz University in Poznań. The authors are very grateful to the geological staff of the Olkusz-Pomorzany zinc and lead mine, ZGH "Bolesław" in Bukowno, in particular to R. Wnuk, M. Grzanka and T. Wójcik for help during sampling and for valuable and significant comments. Special thanks are due to the editor and to the reviewers for valuable and substantive comments, which significantly improved the quality of this article. The authors would also like to thank Dr. D. Michalska for her help during SEM-EDS investigations and M. Kubiak for $\mathrm{XRD}$ analysis.

\section{REFERENCES}

Blowes, D.W., Ptacek, C.J., Frind, E.O., Johnson, R.H., Robertson, W.D., Molson, J.W., 1994. Acid-neutralization reactions in inactive mine tailings impoundments and their effect on the transport of dissolved metals. Environmental Geochemistry of Sulfide Mine Waste, Short Course Handbook, 22: 429-438.

Boni, M., Large, D., 2003. Nonsulfide zinc mineralization in Europe: an overview. Economic Geology, 98: 715-729.

Boni, M., Mondillo, N., 2015. The "Calamines" and the "Others": the great family of supergene nonsulfide zinc ores. Ore Geology, 67: 208-233.

Boni, M., Mondillo, N., Balassone, G., 2011.Zincian dolomite: a peculiar dedolomitization case? Geology, 39: 183-186.

Buła, Z., Żaba, J., Habryn, R., 2008. Tectonic subdivision of Poland: southern Poland (Upper Silesian Block and Małopolska Block) (in Polish with English abstract). Przegląd Geologiczny, 56: 912-920.

Cabała, J., 1996. Occurrence of cerussite and oxidation degree of lead sulphides in $\mathrm{Zn}-\mathrm{Pb}$ ores of the Olkusz-Zawiercie area (in Polish with English summary). Zeszyty Naukowe Politechnik Śląskiej, 230: 223-240.

Cabała, J., 2000. Diversity of $\mathrm{Zn}-\mathrm{Pb}$ ores quality and epigenetic changes of their chemistry in Olkusz region. Gospodarka Surowcami Mineralnymi, 16: 117-141.

Cabała, J., 2001. Development of oxidation in $\mathrm{Zn}-\mathrm{Pb}$ deposit in Olkusz area. Mineral Deposits at the Beginning of the 21st century: 121-124. Balkema.

Cabała, J., 2009. Heavy metals in ground soil environment of the Olkusz area of $\mathrm{Zn}-\mathrm{Pb}$ ore exploitation (in Polish with English summary). Wyd. Uniwersytetu Śląskiego.

Cabała, J., Teper, L., Rutkowski, T., 2004. Rockmass deformations caused by zinc and lead ores mining in the Olkusz region (Southern Poland). Acta Geodynamica et Geomaterialia, 1: $47-58$.

Coppola, V., 2007. The main nonsulphide $\mathrm{Zn}$ deposits in Europe: characterisation, timing and paleoclimatic control. Ph.D. thessis, http://www.fedoa.unina.it/1939/1/Coppola_Scienze_Terra.pdf

Coppola,V., Boni, M., Gilg, H.A., Strzelska-Smakowska, B. 2009. Nonsulfide zinc deposits in the Silesia-Kraków district, Southern Poland. Mineralium Deposita, 44: 559-580.

Gałkiewicz, T., Śliwiński, S., 1985. Geological characteristics of the Silesian-Cracovian zinc-lead ore deposits. Annales Societatis Geologorum Poloniae, 53: 63-90.

Garavelli, C.G., Vurro, F., Fioravanti, G.C., 1982. Minrecordite, a new mineral from Tsumeb. Mineralogical Record, 13: 131-136.
Górecka, E., 1993. Geological setting of the Silesian-Kraków Zn-Pb deposits. Geological Quarterly, 37 (2): 127-146.

Górecka, E., Kozłowski, A., Kibitlewski, S., 1996. The Sielsia-Kraków $\mathrm{Zn}-\mathrm{Pb}$ deposits, Poland: considerations on ore-forming processes. Prace Państwowego Instytutu Geologicznego, 154: 167-182.

Heijlen, W., Muchez, Ph., Banks, D.A., Schneider, J., Kucha, H., Keppens, E., 2003. Carbonate-hosted $\mathrm{Zn}-\mathrm{Pb}$ deposits in Upper Silesia, Poland: origin and evolution of mineralizing fluids and constraints on genetic models. Economic Geology, 98: 911-932.

Hitzman, M.W., Reynolds, N.A., Sangster, D.F., Cameron, A.R., Carman, C.E., 2003. Classification, genesis, and exploration guides for nonsulfide zinc deposits. Economic Geology, 98: 685-714.

Jerzykowska, I., Majzlan, J., Michalik, M., Gottlicher, J., Steininger, R., Błachowski, A., Ruebenbauer, K., 2014. Mineralogy and speciation of $\mathrm{Zn}$ and $\mathrm{As}$ in Fe-oxide-clay aggregates in the mining waste at the MVT $\mathrm{Zn}-\mathrm{Pb}$ deposits near Olkusz, Poland. Chemie der Erde, 74: 393-406.

Kozłowski, A., 1995. Origin of $\mathrm{Zn}-\mathrm{Pb}$ ores in the Olkusz and Chrzanów districts: a model based fluid inclusions. Acta Geologica Polonica, 45: 83-141.

Kozłowski, A., Leach, D.L., Viets, J.G., 1996. Genetic characteristics of fluid inclusions in sphalerite from the Silesian-Kraków ores, Poland. Prace Państwowego Instytutu Geologicznego, 154: 73-83.

Kucha, H., 2003. Mississippi Valley Type Zn-Pb deposits of Upper Silesia, Poland. Europe's major base metal deposits. Irish Association for Economic Geology, Dublin: 253-271.

Lara, R.H., Briones, R., Monroy, M.G., Mullet, M., Humbert, B., Dossot, M., Naja, G.M., Roel, C., 2011. Galena weathering under simulated calcareous soil conditions. Science of the Total Environment, 409: 3971-3979.

Lara, R.H., Monroy, M.G., Mallet, M., Dossot, M., Gonzalez, M.A., Cruz, R., 2015. An experimental study of iron sulfides weathering under simulated calcareous soil conditions. Environmental Earth Sciences, 73: 1849-1869.

Leach, D.L., Viets, J.G., 1992. Comparison of the Kraków-Silesian Mississippi Valley-Type district, southern Poland, with Mississippi Valley-Type districts in North America. United States Department of The Interior U. S. Geological Survey.

Lottermoser, B.G., 2010. Mine wastes. Characterization, treatment an environmental impact: 45-64. Springer, 3rd edition. 
McPhail, D.C., Summerhayes, E., Welch, S., Brugger, J., 2003. The geochemistry and mobility of zinc in the regolith. Advances in Regolith: 287-291.

Nieć, M., Blajda, R., Niedzielski, B., 1993. Zinc-lead ore deposit in Lower Triassic (Roethian) dolomites at Bolesław (Olkusz region, Poland). Geological Quarterly, 37 (2): 157-174.

Osman, AEM, 1989. Smithsonite in the oxidation zone of the Upper Silesia $\mathrm{Zn}-\mathrm{Pb}$ ore deposits (OrzełBiały mine, Bytom area) Poland. Mineralogia Polonica, 20: 57-65.

Plumlee, G.S., 1999. The environmental geology of mineral deposits. Society Economic Geologists Review in Economic Geology, 6A: 71-116.

Radwanek-Bąk, B., 1985. Petrographic characteristic of oxidized zinc ores in the Bolesław and Olkusz deposits (Southern Poland) (in Polish with English summary). Rocznik Polskiego Towarzystwa Geologicznego, 53: 235-254.

Reichert, J., Borg, G., 2008. Numerical simulation and geochemical model of supergene carbonate-hosted non-sulphide zinc deposits. Ore Geology Reviews, 33: 134-151.

Sass-Gustkiewicz, M., Dżułyński, S., 1998. On the origin of strata-bound $\mathrm{Zn}-\mathrm{Pb}$ ores in the Upper Silesia, Poland. Annales Societatis Geologorum Poloniae, 68: 267-278.

Saas-Gustkiewicz, M., Dżułyński, S., Ridge, J. D., 1982. The emplacement of zinc-lead sulfide ores in the Upper-Silesian district-a contribution to the understanding of Mississippi Valley-Type deposits. Economic Geology, 77: 392-412.
Strzelska-Smakowska, B., 2010. Nonsulfide zinc deposits in the Silesia-Kraków district (in Polish with English abstract). Biuletny Państwowego Instytutu Geologicznego, 439: 371-374.

Sutley, S., Sass-Gustkiewicz, M., Mayer, W., Leach, D., 1999. Mineralogy and chemistry of oxidized ores from the Upper Silesia Mississippi Valley-Type zinc-lead deposits, Poland. USGS Open File Report.

Swęd, M., Niedzielski, P., 2018. Geochemistry and mineralogy of technogenic soils developed on old mine heaps of abandoned iron ore mines in the Ławęczna area (Holy Cross Mountains, south-central Poland). Soil Science Annual, 69: 28-38.

Szczerba, M., Sawłowicz, Z., 2009. Remarks on the origin of cerussite in the Upper Silesian $\mathrm{Zn}-\mathrm{Pb}$ deposits, Poland. Mineralogia, 40: 53-64.

Szuwarzyński, M., 1996. Ore bodies in the Silesian-Kraków Zn-Pb ore district, Poland. Prace Państwowego Instytutu Geologicznego, 154: 9-24.

Takahashi, T., 1960. Supergene alteration of zinc and lead deposits in limestone. Economic Geology, 55: 1083-1115.

Żabiński, W., 1960. Charakterystyka mineralogiczna strefy utlenienia śląsko-krakowskich złóż kruszców cynku i ołowiu (in Polish). Prace Geologiczne, 1: 7-99.

Żabiński, W., 1964. Geochemical investigations of the oxidation zone of Silesia-Kraków zinc and lead ore deposit (in Polish with English summary). Prace Geologiczne, 19: 82-84.

Żabiński, W., 1986. Zincian dolomite: the present state of knowledge. A supplement. Mineralogia Polonica, 17: 69-71. 